\title{
THE INVISIBLE MOATS OF THE MUN RIVER VALLEY, NE THAILAND: THE EXAMINATION OF WATER MANAGEMENT DEVICES AT MOUNDED SITES THROUGH GROUND-PENETRATING RADAR (GPR)
}

\author{
Belinda J Duke ${ }^{1}$, Nigel J Chang ${ }^{1}$, Ian Moffat ${ }^{2+3} \&$ Wayne Morris ${ }^{1}$ \\ ${ }^{1}$ James Cook University, ${ }^{2}$ Institute for Mediterranean Studies, ${ }^{3}$ Flinders University
}

\begin{abstract}
The Mun River valley is well known for its moat-bound mounded archaeological sites that are usually associated with Iron Age occupation ( 500BC- AD500). The investigation of these sites has provided a wealth of information on the changing social and environmental conditions during late prehistory. In recent years, research has identified a greater diversity of site morphologies in the region, many of which, importantly, do not appear to have moats surrounding them. This paper seeks to investigate whether the apparently 'non-moated' mound site of Non Klang (Nong Hua Raet village) was actually moated in the past, and if such, now in-filled, features can be investigated using non-destructive Ground-penetrating radar. Additionally, while large external moats can be observed in the modern day topography at sites such as Ban Non Wat, excavation has demonstrated that further, invisible, water management features exist beneath the surface within the current mound boundary of the site. These are probably Iron Age precursors to the later more extensive and still visible moats. This paper seeks to answer several fundamental questions: What application can GPR have at mounded sites in Southeast Asia? Do invisible moats exist? How will this affect our understanding of the broader prehistoric landscape in the Upper Mun River Valley?
\end{abstract}

Keywords: Ground-penetrating radar, moats, mounded sites, Ban Non Wat, Non Klang, Northeast Thailand

\section{INTRODUCTION}

This paper reports on the investigation of two closely neighboring archaeological sites in the Upper Mun River Valley (UMRV) of Northeast Thailand: the moat-bound mound site of Ban Non Wat (BNW) and Non Klang (Nong Hua Raet village) (NHR), a mound site with no visible moats. Moated sites in the Upper Mun River Valley have been of interest to researchers since first identified by Williams-Hunt (1950) in wartime aerial photographs. Most research has emphasized their likely role in the eventual transition from chiefdom to state society (Higham 2014c, O'Reilly 2014). However, it is now apparent that obviously moated sites are only one aspect of

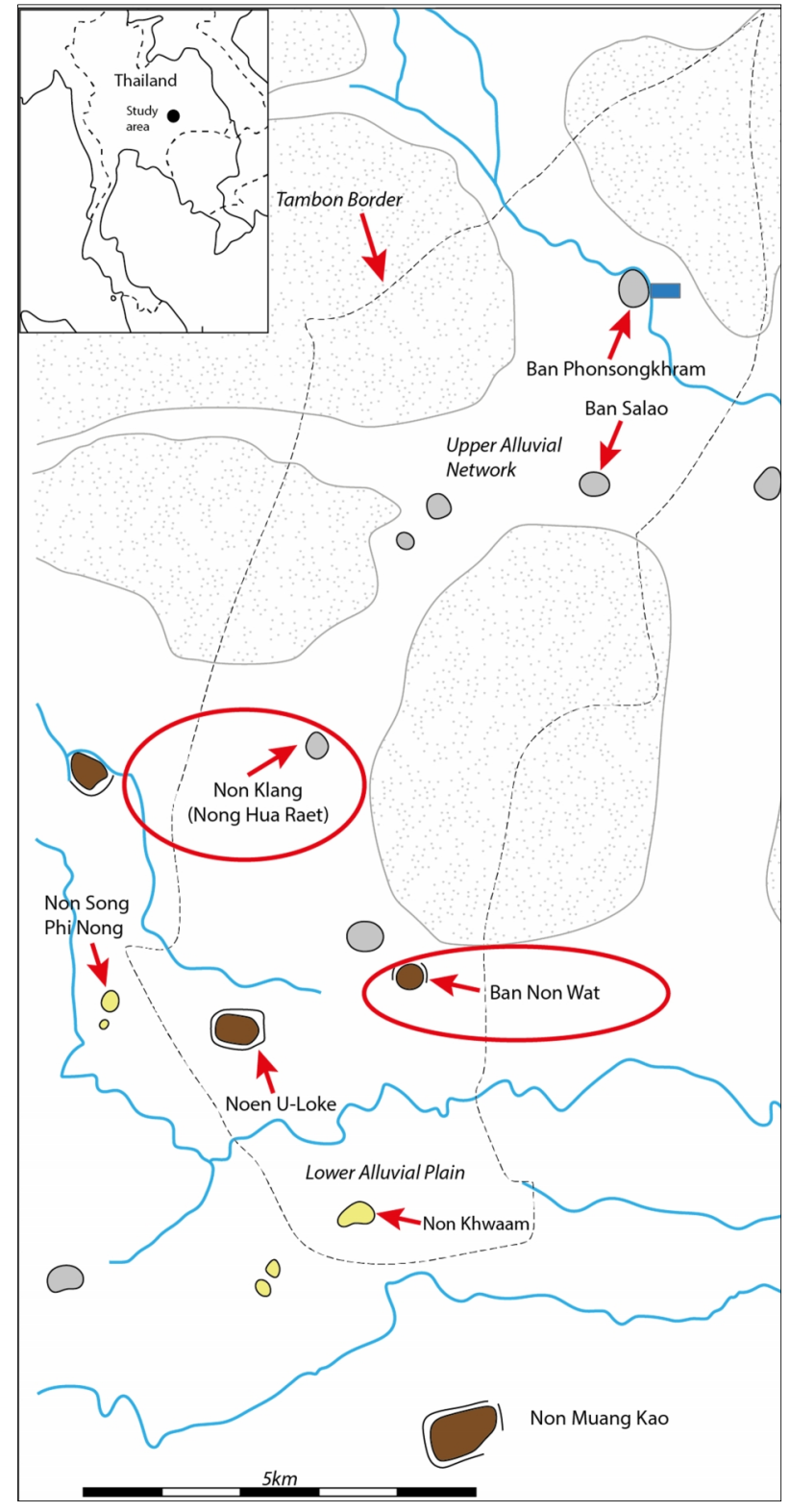

Figure 1: Tambon Phonsongkhram, Thailand, with Ban Non Wat and Nong Hua Raet highlighted. (Moat bound mounds brown, non-moated mounds grey and salt mounds yellow). Courtesy of Pimpicha Bannanurak. 
the Iron Age occupation in the UMRV (Evans 2014). In the local small sub-district of Phonsongkhram, for example, two moat-bound mound sites (Noen U-Loke (NUL) and $\mathrm{BNW})$ are outnumbered by at least six non-moated mounds (Figure 1.). A major aim of this paper is to investigate the relationship between moated and (apparently) non-moated sites in the area with an emphasis on the variety of water control features thought to have been in use during the Iron Age (c. 0- AD600) (Boyd et al. 1999). Having a better understanding of the non-moated sites will provide greater insight into how the region transitioned to state control. The work reported on here was carried out under the 'Society and Environment before Angkor' project with an emphasis on exploring the variety of prehistoric lives within the modern administrative Phonsongkhram sub-district (Non Sung District, Nakhon Ratchasima Province, NE Thailand, see Figure 1).

\section{THE SITES}

BNW is the most extensively excavated site in Phonsongkhram sub-district, and indeed the wider region. Eleven seasons of archaeological investigation have been carried out, beginning with the 'Origins of Angkor' project between 2002 and 2007. This was followed by the 'Society and Environment before Angkor' project between 2007 and 2011 (see Boyd and Chang 2010, Higham and Higham 2009, Higham and Kijngam 2012, Higham et al. 2012, Higham and Kijngam 2010, Higham and Thosarat 2009, Kathilatha et al. 2014a, Kathilatha et al. 2014b). $\mathrm{BNW}$ has one of the longest chronologies of occupation in the region, including the earliest evidence for moat construction during the third century BC (Higham and Higham 2009, McGrath and Boyd 2001). The moats on the Mun River Floodplain have been an important tool in examining changes in social and environmental conditions in the region. It has been argued that moats were constructed using hydrological means by building ramparts and diverting now extinct rivers to flow around the mound sites (McGrath and Boyd 2001, McGrath et al. 2008). The moats themselves are flat bottomed and relatively shallow, with no evidence of defensive fortification, which McGrath and Boyd (2001) suggest is more indicative of water management than warfare. The presence of rice grains at the base of the inner moats of neighboring sites further suggests an agricultural purpose (McGrath and Boyd 2001).

The construction of the moats in this region has been related to the emergence of elites and the transition to state society (Higham 2014a, Higham 2014b, O'Reilly 2014). O'Reilly (2014) has argued that the presence of these moats allowed for a staple-finance system to flourish where access to water for rice production was central to dominance over the population. Others have emphasized the relationship between the appearance of moats and the onset of more arid environmental conditions (Boyd et al. 1999, Habberfield-Short and Boyd 2007, McGrath and Boyd 2001, and McGrath et al. 2008). The difference between moated and non-moated sites was touched on by Moore $(1989,1988)$; further investigated by Murphy (2013) in relation to historic period Sema stones and also by McNeill and Welch (1989), Welch (1989, 1998) and Welch and McNeill (1994) examining the distribution of sites on the floodplain. Expanding the current research to investigate if moats were originally present at apparently non-moated sites in the region will aid in this research and further expand our understanding of changing social complexity in the region.

Despite the intensity and longevity of investigation, no more than $2 \%$ of the BNW site has been excavated, leaving much unknown about the full range of activities carried out by past communities. The 'Society and Environment before Angkor' project aimed to address this by placing smaller excavation pits more broadly across the site. One result of this was the discovery of a major buried water channel that appears to date to the Iron Age (Duke 2009, Kathilatha et al. 2014a, Kathilatha et al. 2014b). This find raises the possibility of a long sequence of development and modification of moats at these sites, as well as demonstrating that such features do exist hidden beneath the modern topography.

In contrast, just a single season of archaeological excavation has been carried out at NHR in 2010 as part of the 'Society and Environment before Angkor' project strategy to compare moated and (apparently) non-moated sites with Phonsongkhram sub-district. The site was selected due to its unique location as an apparent island within an ancient river system, as well as the very sandy substrate that suggested a different use of the site (compared with BNW). Excavations on one of the highest points on the mound showed occupation beginning near the end of the Bronze Age and continuing through to the end of the Iron Age, with no evidence of Neolithic or early Bronze Age deposits (Kathilatha et al. 2014a, Kathilatha et al. 2014b). The earliest radiocarbon determinations are from 2.2 meters below datum from a hard floor at $2559 \pm 111$ years BP (Kathilatha et al. 2014a:6). No burials were recovered. However, significant potterysherd dominated middens were identified at lower levels, dating to around the transition from Bronze to Iron Age (see Table 1). These middens were associated with semicircular furnace-like structures composed of baked clay, similar to those reported by Duke et al. (2010) at BNW.

Table 1: Radiocarbon dates on charcoal in sediment samples from soil profiles at NHR (Kathilatha et al. 2014a: 6).

\begin{tabular}{llllll}
\hline $\begin{array}{l}\text { Lab } \\
\text { Code }\end{array}$ & Layer & Spit & Height & $\begin{array}{l}\text { Conventional } \\
\text { radiocarbon } \\
\text { Age (BP) }\end{array}$ & $\begin{array}{l}\text { Years Cal. } \\
\text { BP }\end{array}$ \\
\hline OZO717 & 3 & 9 & 2.2 & $2450 \pm 30$ & $2539 \pm 125$ \\
OZO718 & 3 & 10 & 2.2 & $2275 \pm 30$ & $2272 \pm 65$ \\
OZP207 & 3 & 10 & 2.2 & $2465 \pm 35$ & $2559 \pm 111$ \\
\hline
\end{tabular}

Given that NHR was occupied through the same centuries as moats were being constructed and used at nearby $\mathrm{BNW}$, and the experience of discovering previously unknown constructed water channels, also at BNW, the question of the potential existence of original moats, now buried, at NHR was raised. 


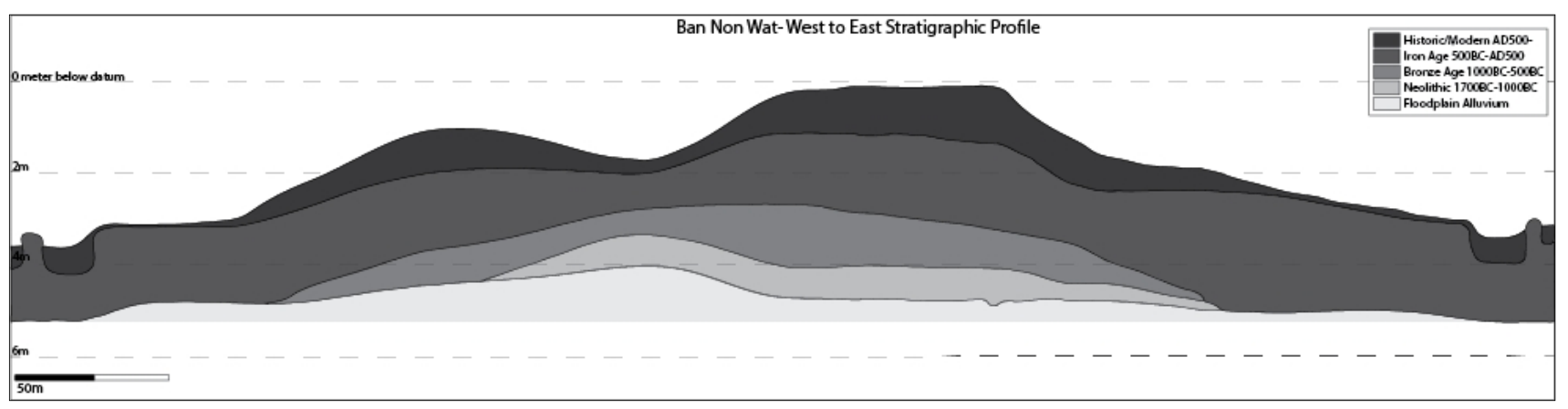

Figure 2: Cross section of BNW showing the stratigraphic growth of the mound by cultural period, extrapolated from excavation unit profiles distributed from east to west across the site.

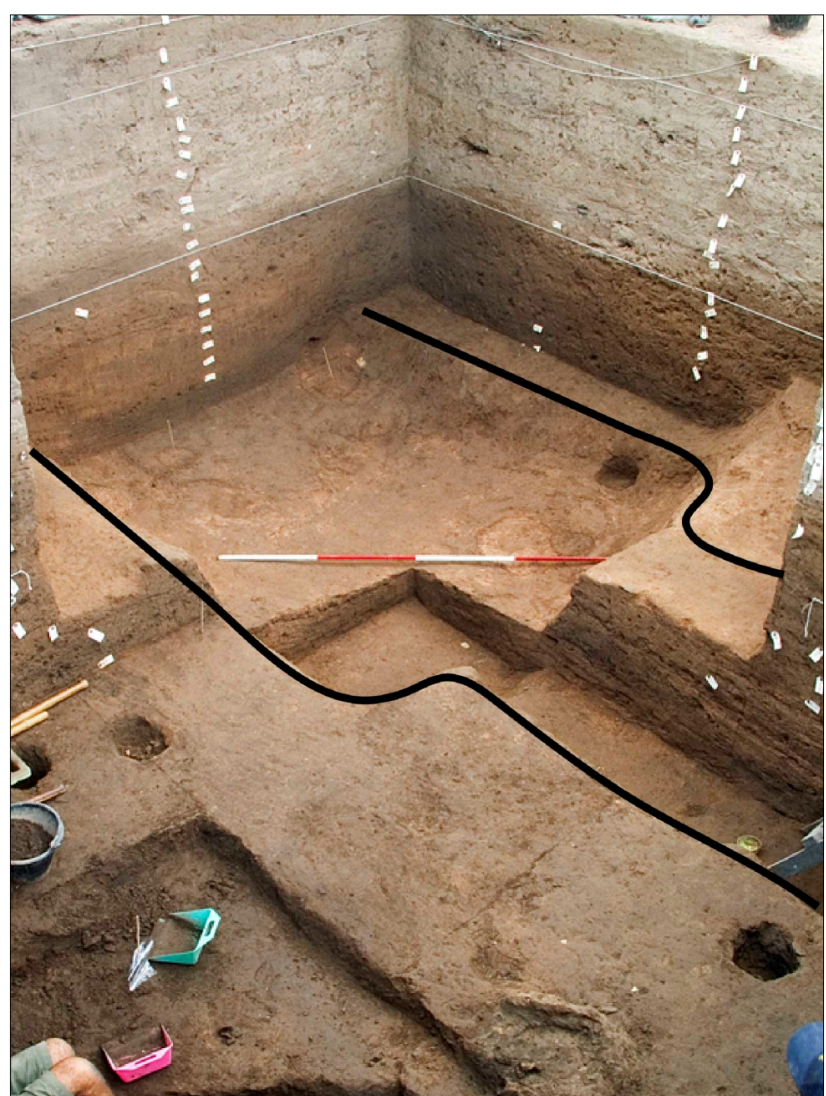

Figure 3: Water management device at Ban Non Wat investigated by Duke (2009) and investigated below in GPR survey.

GPR was considered an appropriate methodology to apply to this question and its application and the results are discussed in following sections.

\section{GROUND-PENETRATING RADAR (GPR)}

Little research has been conducted using GPR to investigate mound sites in Southeast Asia. Traditionally, GPR is used in survey stages of archaeology as a means to locate sites or to determine their extent. GPR has been applied to mound sites in Europe and the Middle East, with empha- sis on identifying large scale features such as burial chambers and changes in sediment deposition (see Forte and Pipan 2008, Persson and Olofsson 2004, Sarris et al. 2013, Urban et al. 2014, Whittaker and Storey 2008). The use of GPR on mound sites in these studies was limited by the depth and density of the sites, with researchers emphasizing the need to combine GPR with other geophysical methods. The success in finding large-scale features is encouraging for the potential application of this method to Southeast Asian contexts.

Successful GPR projects conducted in Asia include Choi et al. (2014) who investigated Holocene coastal barriers and sea level change in South Korea; Yong et al. (2001) who used GPR reflection configurations to examine sedimentary succession and the internal structure of barrier-lagoon stems of coastal Boao on Hainan Island, China; Sonnemann (2011) at Angkor, Cambodia who tested the limitations and potential for GPR in the region looking at cemeteries, production sites and habitation patters; and Sonnemann and Chhay (2014) who used GPR to investigate Angkorian ceramic kilns at Bangkong, Siem Reap. Despite the kilns not being visible on the surface, and in the absence of destructive excavation, the geophysical survey was able to develop a $3 \mathrm{D}$ visualization of the shape, depth and extent of the kilns. In addition to this research Sonnemann (2015a, 2015b) investigated water management at Angkor. The classification and characteristics of moats and channel features at historical Angkorian sites presented by Sonnemann (2011) will be used as a comparison to the prehistoric features presented below.

Common to these examples, is the recognition that GPR is an important tool which can be added to archaeological surveys to gain a better understanding of archaeological and geomorphological features in the subsurface, which would be particularly useful at mounded sites of the types found in NE Thailand. The methodological aim of this paper is to test the limits of GPR survey in tropical locations such as NE Thailand, and examine under what conditions this apparatus is best used. Understanding the technology and its limits is important for future archaeological research in this region, as is having a sound understanding of the site structure and archeological components before conducting surveys. 
Site structure and the Archaeology

\section{Ban Non Wat}

The structure and archaeology of BNW is highly complex and deeply stratified. The site is notable for being a multicomponent site with habitation from the Neolithic through Historic periods (Duke 2014, Kathilatha et al. 2014a). Figure 2 demonstrates how the site has built up from a small natural mound of alluvial silt, clay and laterite on the floodplain. During the Neolithic and Bronze Age the site appears to have experienced rapid sediment accumulation and a significant increase in topographic relief, particularly on the external edges of the mound (Duke 2014). This is the result of intensive anthropogenic activity on the mound, particularly involving the emplacement of human burials, slag from metal production and the construction of living floors (Duke et al. 2010, Kathilatha et al. 2014a).

Iron Age modifications to the mound include the construction of moats and smaller internal water management features on the mound itself (Duke 2009, McGrath and Boyd 2001). Figure 3 shows an internal water management feature, or ditch, outlined in black, uncovered at Ban Non Wat. While their exact chronology is unclear, these ditches may have been precursors to the still visible moats, and used as a means to manage dwindling water supplies during a period of increasingly arid climate (Boyd and McGrath 2001, Duke 2009). This feature is surrounded by evidence for metal, pottery and salt production on working surfaces; these activities leave characteristic mineral rich deposits (Duke et al. 2010). During the Iron Age, much activity appears to be concentrated on the outer edges of the mound. The sediment accumulated during the Iron Age derives from the surrounding alluvial floodplain and mainly consists of fine silt and loam (Kathilatha et al. 2014a). There have been limited expressions of the Historic and modern periods in the excavations at BNW. The site's highly complex structure and archaeology makes fine grained GPR survey very challenging, however, as Forte and Pipan (2008), Persson and Olofsson (2004) and Whittaker and Storey (2008) have demonstrated, the examination of large scale features, such as water management devices, is likely to be much more rewarding at highly stratified mounded sites.

\section{Nong Hua Raet (Non Klang)}

The site appears to have been a small bank detached sand bar within a river system when it was initially occupied during the late Bronze Age and as a result, the mound consists of mostly sandy loam overlying the silt of the alluvial floodplain. The mound primarily consists of sandy layers with inclusions of archaeological material (Kathilatha et al. 2014a). Most notably, no moats or other water control features are visible at the site, despite its occupation during the early Iron Age and its proximity to water sources that could have been diverted or channelled to create a moat network. The structure and low frequency of archaeological material at NHR makes it a much more promising candidate for GPR prospection than BNW.

\section{METHODOLOGY}

GPR is a geophysical technique that works by transmitting radar energy subsurface to reflect off the boundaries between features with different physical properties. The depth of these features can be determined by measuring the time taken for the energy to return to the surface. The information can be quickly collected for large areas in 2D profiles or $3 \mathrm{D}$ data cubes which can contribute significantly to answering archaeological questions (Conyers 2010, 2012, 2013). As well as being suitable for mapping archaeological material, GPR can also be used to map stratigraphic changes such as palaeo-channels or subsurface disturbance (Bristow and Jol 2003).

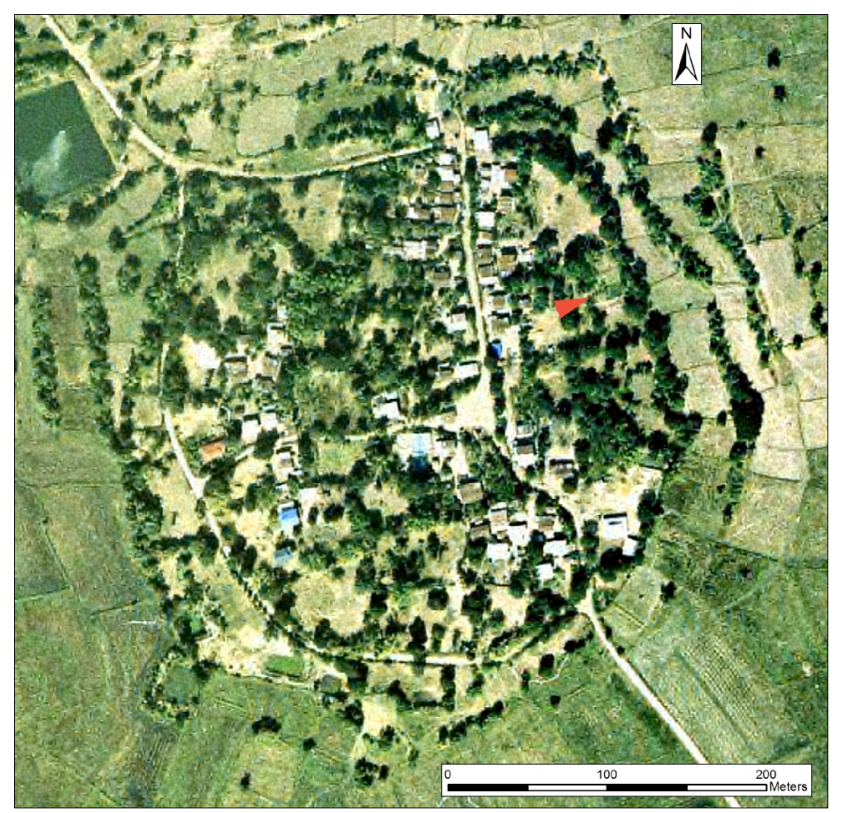

Figure 4: BNW with position and direction of survey indicated.

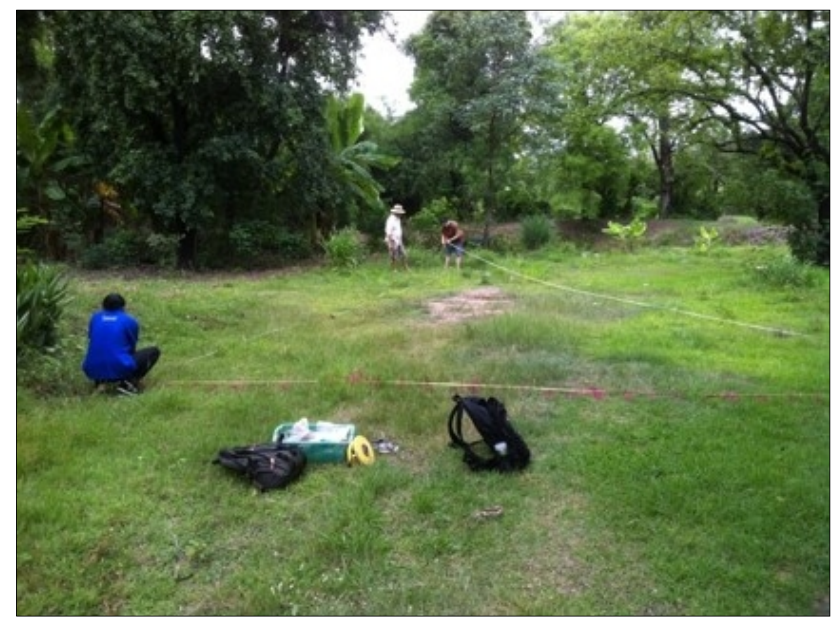

Figure 5: Area surveyed at BNW, looking downhill towards eastern moats. 


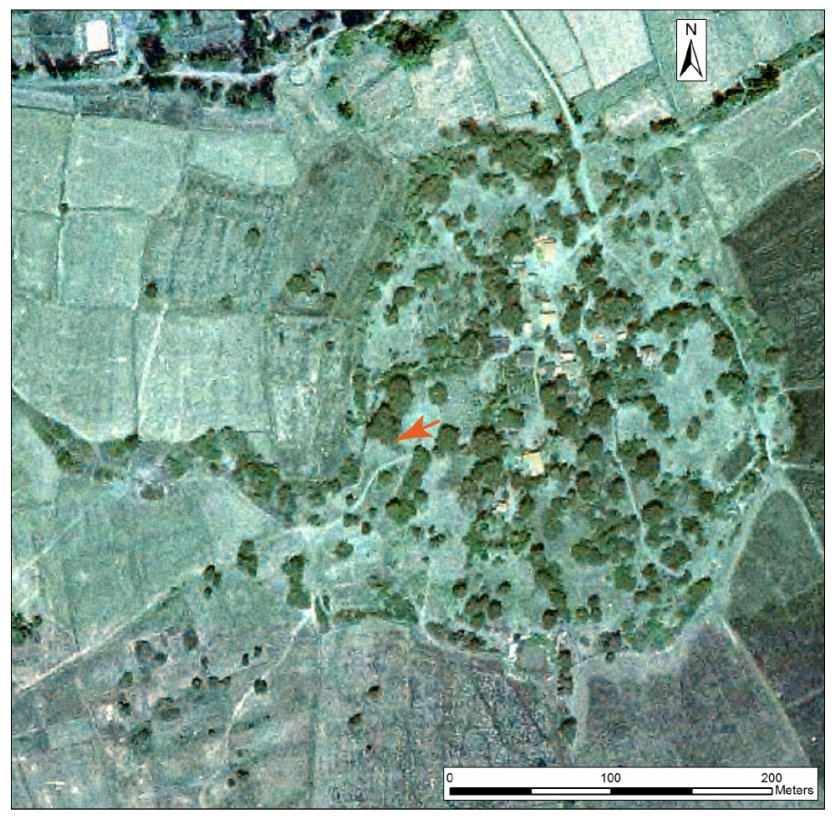

Figure 6: NHR with position and direction of survey indicated.

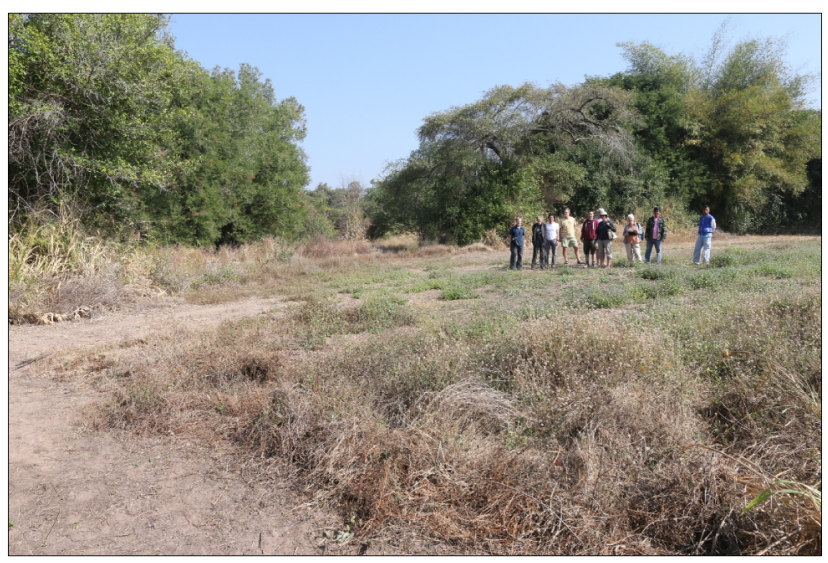

Figure 7: Area surveyed at NHR looking north-west toward the centre of the mound.

The GPR surveys reported on here were conducted in June 2011 at both BNW and NHR. The area surveyed at BNW was located immediately adjacent to the excavation pit (see Figures 4 and 5) that had previously revealed a buried water channel identified in Figure 3 with the aim of identifying what geophysical signature was associated with this sort of feature. This was located on the eastern edge of the mound. The area surveyed at NHR was chosen because of its proximity to the edge of the mound and the open and relatively flat aspect (Figures 6 and 7).

The GPR survey was undertaken using a RAMA/Mala $\mathrm{X} 3 \mathrm{M}$ with a $250 \mathrm{MHz}$ antenna mounted in a survey cart. Acquisition settings included collecting 264 samples and 4 stacks per trace, using a time window of $69 \mathrm{~ns}$ and a trace increment of $20 \mathrm{~mm}$. Where possible a standard 20x20 meter survey grid was used, deploying bidirectional sampling with $0.5 \mathrm{~m}$ intervals between each traverse.
Soil velocity was estimated at $0.07 \mathrm{~m} / \mathrm{ns}$ based on hyperbola fitting. Processing was undertaken using ReflexW software and profiles were combined into a 3D cube using a linear weight interpolation and displayed as enveloped data to accentuate the appearance of high amplitude features in subsurface deposits. Anomalies and potential features were identified by post-processing, and cross referenced to examples provided by Conyers $(2012,2013)$.

\section{RESULTS}

\section{Ban Non Wat}

The resultant GPR data is dominated by multiple small point source anomalies. These probably reflect discrete items of material culture with a significant relative dielectric permittivity contrast from the background. The degree of signal attenuation changes significantly across individual profiles, suggesting rapid variations in clay abundance in the subsurface. The stratigraphy is generally confused other than occasional, very prominent, changes which appear to be anthropogenic (Figure 8).

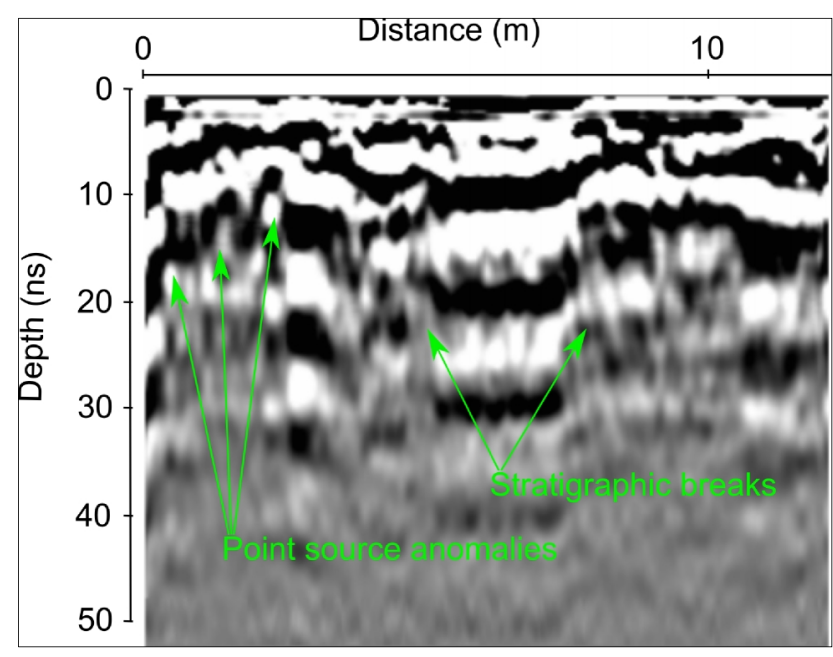

Figure 8: GPR profile from Ban Non Wat. A selection of stratigraphic breaks and point source anomalies are highlighted.

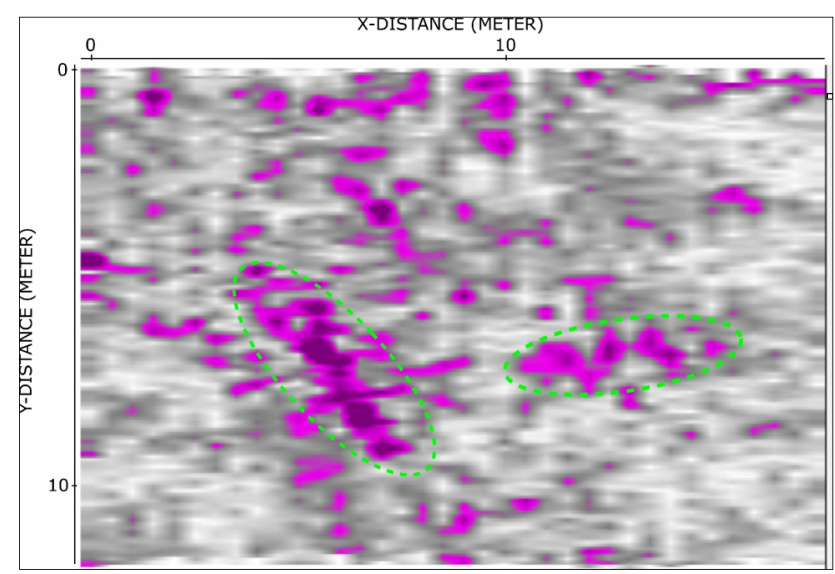

Figure 9: GPR 3D amplitude map from a depth of $\sim 0.96 \mathrm{~m}$ to $1.20 \mathrm{~m}$ from Ban Non Wat. Linear, high amplitude features are highlighted. 


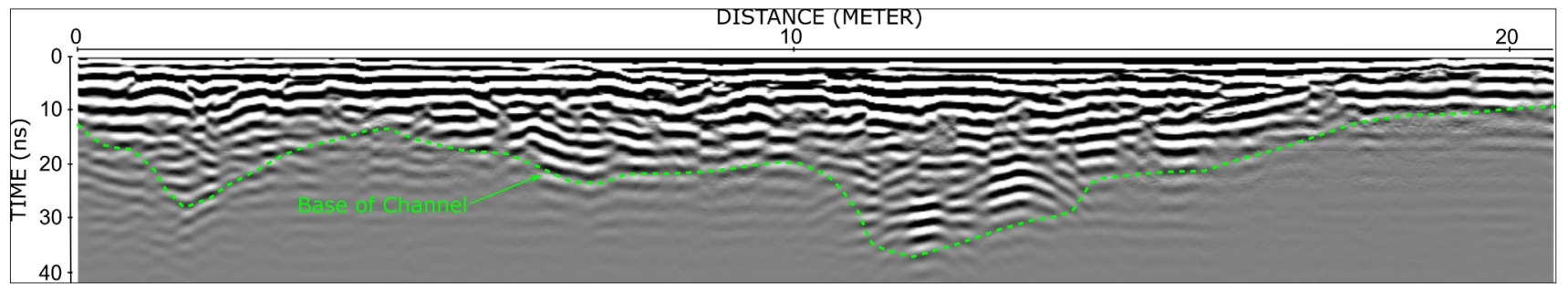

Figure 10: GPR Profile from Nong Hua Raet showing multiple incised channel features. This profile runs from east (left, at the base of the mound's east edge) to west (further into the mound).

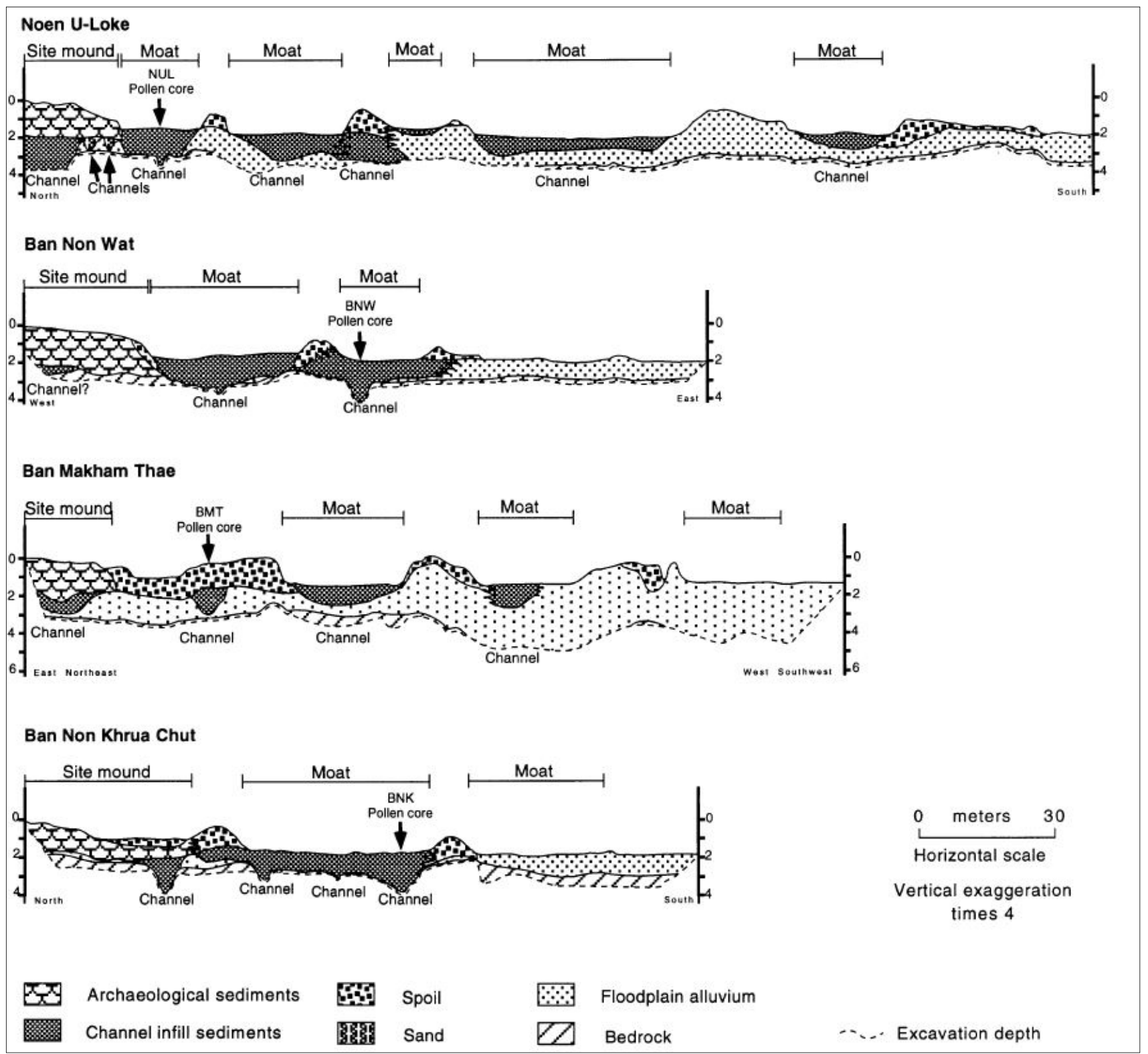

Figure 11: Section of moats from archaeological sites in the UMRF region demonstrating the flat bottomed and shallow structure similar to that found in Feature 10 (from Boyd and McGrath 2001: 312).

The width of the feature represented by stratigraphic breaks in Figure 8 (c. $3 \mathrm{~m}$ ) is consistent with the archaeological feature excavated and recorded in the adjacent excavation pit (Figure 3). The 3D time slice reveals linear features with high amplitudes that also appear to be anthropogenic (highlighted in green in Figure 9. 


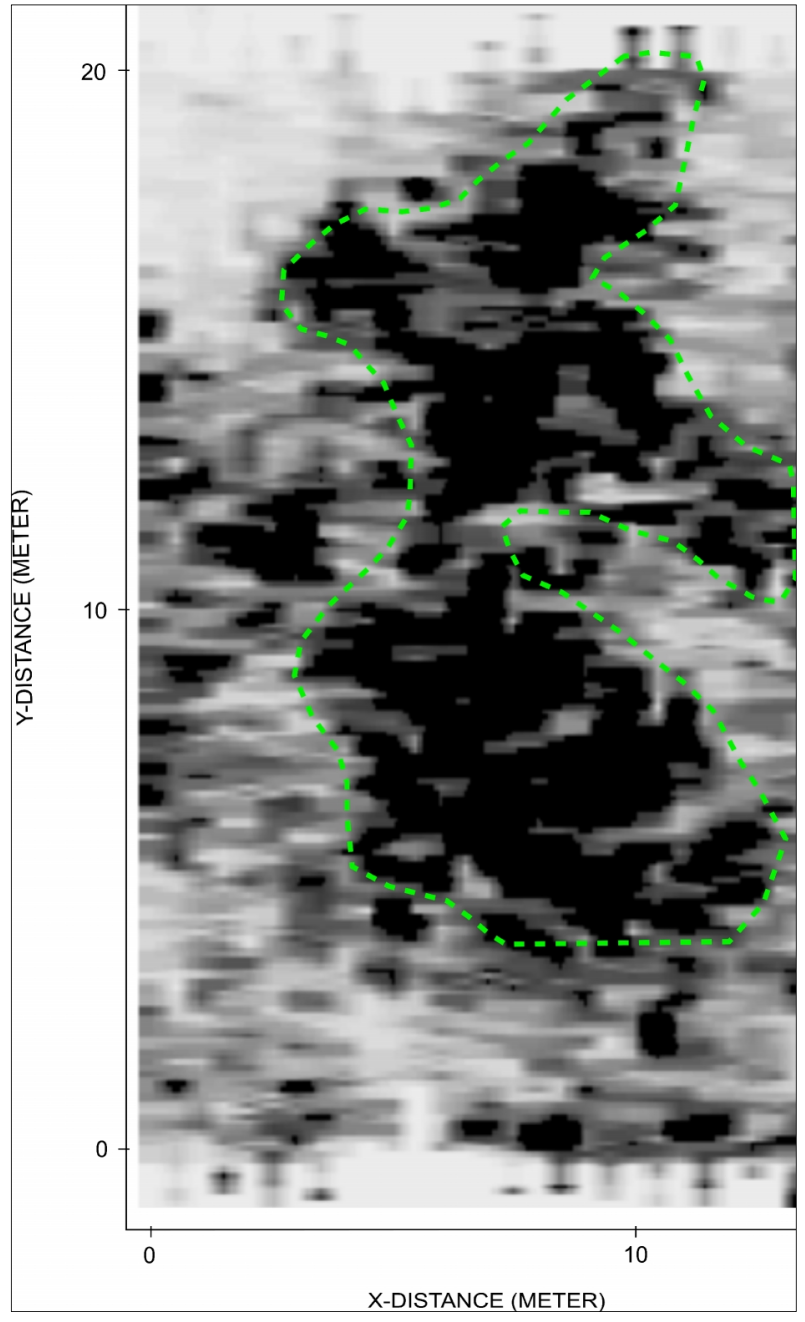

Figure 12: 3D amplitude map from 0.9-1m depth at Nong Hua Raet with a complex, high amplitude feature highlighted.

Anthropogenic disturbance is found throughout the profile of the neighbouring excavation pit. Such disturbances may be reflected in Figure 9 as these features are not consistent with the excavated water channel feature. Metal production surfaces and features as noted by Duke et al. (2010) are in the form of burnt clay features related to furnaces, in addition to the inclusion of metallurgical slag and discarded metal such as bronze and iron. The highly reflective nature of the metal is consistent with the high amplitude features seen on the 3D time slice.

\section{Nong Hua Raet}

GPR data from Nong Hua Raet indicates multiple incised channel features with a disordered, though well resolved, internal stratigraphy (Figure 10). These features show far less signal attenuation than their surrounding material, suggesting they may contain a higher proportion of sand than the surrounding and underlying substrates. There are considerably less point source anomalies within the fill compared to Ban Non Wat, reflecting the low levels of cultural material which was found during excavations higher on the mound. The morphology of the incision shows a remarkable similarity to cross sections from anthropogenic moats at other sites in the area (shown in Figure 11), suggesting that this may be a water management device (or at least an anthropologically modified feature) rather than a natural fluvial system. This hypothesis is supported by the complex series of sedimentary structures evident in the shallow subsurface that suggest significant anthropogenic modification during the filling of these features. Similarly the 3D GPR data from NHR shows that the high amplitude (potential moat?) feature has a complex morphology with a number of lobes and varying width which is unlike the meandering channel systems which dominate in this area.

\section{DISCUSSION}

\section{GPR Prospection at BNW}

Due to the complex and deep stratigraphy of the site and the density of the associated archaeological material, the GPR was not able to map small-scale archaeological features. Factors such as chemical signatures associated with metal, salt and pottery production, the general abundance of archaeological material and rapid variation in clay content all affect the degree of attenuation in the area. GPR survey did successfully identify the constructed water channel at BNW, based on clearly defined stratigraphic breaks. The adjacent high amplitude features that we suggest are related to metal production at the site can also be clearly identified. It would be interesting to test this hypothesis with future targeted archaeological excavation.

Outside of large features such as the water channel, we predict that the most revealing results will be obtained at the furthest boundaries of the mound where the surface is relatively flat and where there are fewer layers of subsurface deposition, thus allowing individual features to stand out from the background data. Again, a programme of geophysical prospection and targeted archaeological excavation would be useful here to test this idea. As Whittaker and Storey (2008) and Persson and Olofsson (2004) argue, GPR and other non-destructive geoarchaeological methods need to be a part of a process which incorporates additional geophysical methods, alongside destructive methods of analysis such as excavation to generate a holistic approach to investigating mound sites. Despite the difficulties, the success of identifying some features at BNW was encouragement for taking the GPR to investigate the NHR site.

\section{Unveiling "Invisible" Moats at NHR?}

The GPR survey on the western edge of the mound at NHR has identified a flat-bottomed moat-like feature. The success of GPR survey here can be attributed to the relatively shallow depth of the feature, and the well-drained (and therefore dry) sediments, which provided ideal conditions for GPR survey and signal attenuation. The conditions were such that well resolved internal stratigraphy of this feature could be identified leading to the conclusion that the original channel was filled in over time by mostly natural alluvial processes. 
The width of this feature $(\sim 10-12$ meters $)$ is consistent with the still visible moats at sites such as BNW (Figure 4). Further, aerial photography (Figure 13) also indicates what may be the remains of a stream that flowed past the western edge of the site. If a moat or water management device was built, it most likely took advantage of the existing river system capturing water for later use (following the McGrath's (2001) and Boyd et al.'s (1999) model for the development of moats in NE Thailand).

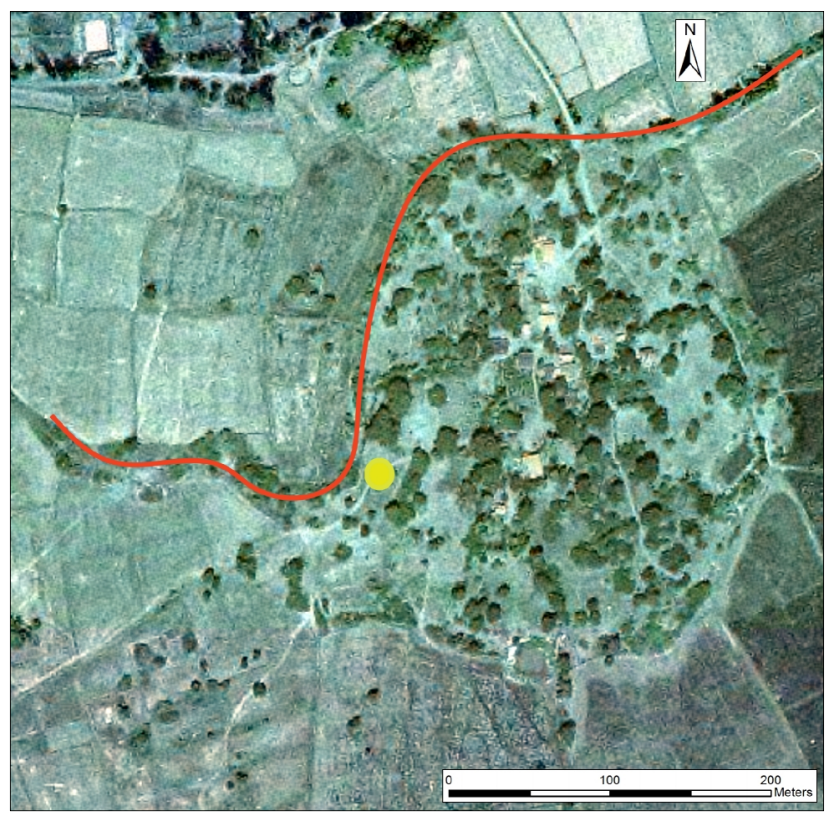

Figure 13: NRH mound with potential extinct river system highlight in red with placement of survey indicated in yellow.

While 'ground-truthing' in the form of archaeological excavation has not yet been done, we have at least an indication that GPR can be used to investigate the presence of moats or similar features that may have become buried and invisible over millennia of site expansion in NE Thailand. Preliminary results from NHR suggest that now invisible water management devices were once employed at this site where active rivers or streams were diverted to make moats. The argument is stronger when we take into account the GPR findings at BNW.

What then are the implications of these findings? Water management has been cited by O'Reilly (2014) as an important tool for developing and maintaining civilisations. Thus, the presence and development of water management devices in the UMRV Iron Age should be important evidence for understanding changing social complexity. To this end, O'Reilly (2014) has further proposed that moats were a part of a water storage network aimed at generating a rice surplus in an increasingly complex Iron Age period. O'Reilly (2014:303) hypothesised that a site like BNW, with an estimated population of 308 people could generate enough rice to feed 445 people, with similar figures assigned to other neighbouring moated sites. However, this model has only considered moated sites. NHR is an example of one of the many apparently non-moated mound sites that are now known to have existed alongside the moated sites. Acknowledging this more complex cultural landscape leads us down (at least) two new interpretive paths.

First, it may be that sites such as NHR were indeed devoid of moats (with the implication that the feature identified by GPR is a natural channel). In this case models that only account for populations and potential surpluses at individual moated sites will, at the very most, only be seeing a small part of the complete picture. It should be noted that BNW and NHR lie just $3 \mathrm{~km}$ apart - a very short walk - and we argue that they should be considered component parts of a single larger community during the Iron Age (and possibly earlier). If this is correct then BNW (and other close-by villages such as NUL) may have been the 'rice-bowls' of this community with sites like NHR contributing other resources such as salt and easy access to forest-collected products such as mushrooms or perhaps grazing for domestic cattle and hunting for deer (Gordon Stenhouse, pers. comm.).

Alternatively, the GPR work at NHR may really be showing us that moats did once exist at this site and it is simply taphonomy that separates sites such as NHR and $\mathrm{BNW}$. If this is the case then it is crucially important that excavations be carried out at non-obviously moated sites to confirm the presence and scale of moats and/or other water management systems. O'Reilly's (2014) system of ranking UMRV sites on the basis their capacity to retain water and generate surpluses will need to be considerably extended. Further, it is unlikely that any putative 'invisible' moats were of the same scale and type as those that remain visible at BNW and NUL.

What these alternative hypotheses share is an acknowledgement that the cultural and technological landscape of the Iron Age UMRV is likely to be much more complex than previously considered. Many different villages placed in differing but adjacent ecological zones likely formed inter-related communities with economic systems that went well beyond a simple ability to produce a rice surplus. The geophysical prospection reported on here has been important in revealing some of this complexity.

The presence or absence of moats may also be important in developing a better understanding of the relationship between developing social complexity and mortuary traditions in the UMRV. Social complexity has been measured by Higham (2014c) based on the presence of complex burial traditions at moated sites such as BNW and NUL. If the building of moats is also related to an increase in social complexity (cf O'Reilly 2014) how might we account for NHR where we think at least one moat did exist, but where our $4 \times 8 \mathrm{~m}$ excavation failed to recover any burials at all. On the other hand, our excavation at Ban Salao, another apparently non-moated mound site located seven kilometres north of BNW, has revealed a well-endowed Iron Age infant grave at the base of the $4 \times 4 \mathrm{~m}$ excavation unit. At Ban Phonsongkhram, another apparently non-moated site, residents report that Iron Age burials are frequently disturbed when digging in the vil- 
lage. Again, we argue that future models of social organization and complexity will need to be developed based on a better understanding of the likely variety of site types that made up communities (Evans 2014).

It may be that sites such as BNW and NUL with a coincidence of complex burial patterns and multiple moats were the centres of power for Iron Age chiefdoms, combining capacity to store water and generate a rice surplus with control over subsidiary villages and hamlets such as NHR. However, much more intensive archaeological and geophysical investigation (including other methods such as electromagnetic induction and electrical resistivity tomography), aimed, in particular, at understanding the nature of water management, is required to show if this was the case.

\section{CONCLUSIONS}

The application of GPR in NE Thailand has been successful in identifying buried water management devices (channels) at mounded archaeological sites. Although the GPR surveys at BNW had limited success in identifying smaller archaeological features, this study has highlighted the potential for this method in examining large-scale features in future research projects. A combination of GPR with additional non-destructive geophysical methods and (destructive) archaeological excavation will allow for new information to be gathered in the future.

Preliminary GPR results from NHR suggest that a large-scale water feature was present on the margin of this apparently non-moated site. Future targeted excavations will be required to identify the exact nature of this feature, in particular if it is an anthropogenic moat or, alternatively, a natural fluvial feature running adjacent to the prehistoric site. As noted by one reviewer, the two interpretations are not necessarily mutually exclusive; we may have an opportunity to examine the early stages of transformation from a natural waterway into a built moat in this region (cf McGrath and Boyd 2001, McGrath et al. 2008).

In any case, perhaps the most important concluding point is that continuing to investigate the variety of sites present on the Mun River floodplain, employing the full range of techniques at our disposal, in particular GPR, will be crucial to a better understanding of the variety of communities and the complexity of the cultural landscape during the Iron Age and, indeed, other periods of prehistory. From this, more light will be shed on the issue of the development of social complexity in NE Thailand.

\section{ACKNOWLEDGEMENTS}

The authors would like to thank the Earthwatch Institute for their on-going funding for archaeological research in NE Thailand and the many volunteers who visit and work on these projects. Many thanks to the National Research Council of Thailand and the Fine Arts Department of Thailand for allowing this research to be conducted. We also thank Ms Pimpicha Bannanurak for her assistance in the field collecting data and the wonderful people of Ban Non Wat \& Tambon Phon Songkhram for letting us conduct surveys in and around their homes. This project was supported by James Cook University, Kasetsart Univeristy, Nakhon Ratchasima Rajhabhat University, and Southern Cross University and the Society and Environment before Angkor Project Leaders: Kate Domett (JCU), Warrachai Wiriyaromp (KU), Amphan Kijngam (FAD), William Boyd (SCU), Nigel Chang (JCU). Thank you to Dr Alison Carter for your insights and revisions and to the reviewers for their contributions.

\section{REFERENCES}

Boyd, W. E. \& Chang, N. 2010. Integrating Social and Environmental Change in Prehistory: A Discussion of the Role of Landscape as a Heuristic in Defining Prehistoric Possibilities in Northeast Thailand. In: Haberle, S., Stevenson, J. \& Prebble, M.(eds.) Altered Ecologies: Fire, Climate and Human Influence on Terrestrial Landscape. 273-297. Canberra ANU E Press.

Boyd, W. E., Higham, C. \& McGrath, R. J. 1999. The Geoarchaeolog of Iron Age "Moated" Sites of the Upper Mae Nam Mun Valley, N.E. Thailand. I" Palaeodrainage, SiteLandscape Relationships and the Origins of the "Moats". Geoarchaeology: An International Journal, 14: 675-716.

Boyd, W. E. \& McGrath, R. J. 2001. The Geoarchaeology of the Prehistoric Ditched Sites of the Upper Mae Nam Mun Valley, Ne Thailand, III: Late Holocene Vegetation History. Palaeogeography, Palaeoclimatology, Palaeoecology, 171(3-4): 307-328.

Bristow, C. \& Jol, H. (eds.) 2003. Ground-penetrating radar in Sediments, Geological Society, London: Special Publications 211

Choi, K. H., Choi, J.-H. \& Kim, J. W. 2014. Reconstruction of Holocene Costal Progradation on the East Coast of Korea Based on OSL Dating and GPR Surveys of BeachForedune Ridges. The Holocene, 24(1): 24-34.

Conyers, L. B. 2010. Ground-Penetrating Radar for Anthropological Research. Antiquity, 84(323): 175-184.

Conyers, L. B. 2012. Interpreting Ground-Penetrating Radar for Archaeology Walnut Creek, Left Coast Press.

Conyers, L. B. 2013. Ground-Penetrating Radar for Archaeology, Maryland, AltaMira Press.

Duke, B. J. 2009. This Is Not a Moat: Water and Boundaries at Ban Non Wat, Northeast Thailand. Unpublished Dissertation, James Cook University, Townsville.

Duke, B. J. 2014. The Invisible Moats of the Mun River Valley Mounded Sites: The Examination of Site Formation through GPR. 20th Congress of the Indo-Pacific Prehistory Association. Siem Reap, Kingdom of Cambodia.

Duke, B. J., Carter, A. K. \& Chang, N. J. 2010. The Excavation of Iron Age Working Floors and Small-Scale Industry at Ban Non Wat, Thailand. Paper from the Institute of Archaeology, 20: 123-130.

Evans, C. 2014. The Transition from Iron Age to Proto-History in Northeast Thailand: A Multi-Scalar, Nested Approach. 20th Congress of the Indo-Pacific Prehistory Association. Siem Reap, Kingdom of Cambodia.

Forte, E. \& Pipan, M. 2008. Integrated Siesmic Tomography and Ground-penetrating radar (GPR) for the HighResolution Study of Burial Mounds (Tumuli). Journal of Archaeological Science, 35: 2614-2623.

Habberfield-Short, J. \& Boyd, W. E. 2007. The Geoarchaeological Development of Noen U-Loke and Mon Muang Kao. 
In: Higham, C. F. W. \& Thosarat, R.(eds.) The Origins Of the Civilisation of Angkor: The Excavation of Noen $U$ Loke and Mon Muang Kao. 55-74. Bangkok, The Thai Fine Arts Department.

Higham, C. 2014a. Early Mainland Southeast Asia: From First Humans to Angkor, Bangkok, River Books.

Higham, C. 2014b. From Paddy to Pura: Excavations at Non Ban Jak, Northeast Thailand and the Origins of Early States. 20th Congress of the Indo-Pacifric Prehistory Association. Siem Reap, Kingdom of Cambodia.

Higham, C. 2014c. From the Iron Age to Angkor: New Light on the Origins of a State. Antiquity, 88: 822-835.

Higham, C. \& Higham, T. 2009. A New Chronological Framework for a Prehisoric Southeast Asia, Based on a Bayesian Modle from Ban Non Wat. Antiquity, 83(319): 125144.

Higham, C. \& Kijngam, A. 2012. The Origins of the Civilisation of Angkor, Volume V: The Excavation of Ban Non Wat: The Bronze Age, Bangkok, The Fine Arts Department of Thailand.

Higham, C., Thosarat, R., Cameron, J., Carter, A. K., Geary, R., Iseppy, A., Lankton, J., Manly, B. F. J. \& Sarjeant, C. 2012. The Origins of the Civilisation of Angkor Volume VI: The Excavation of Ban Non Wat: The Iron Age, Summary and Conclusions, Bangkok, Thai Fine Arts Department

Higham, C. F. W. \& Kijngam, A. (eds.) 2010. The Origins of the Civilisaton of Angkor, Volume IV: The Excavation of Ban Non Wat: The Neolithic Occupation, Bangkok: The Thai Fine Arts Department.

Higham, C. F. W. \& Thosarat, R. 2009. The Origins of the Civilisation of Angkor, Volume III: The Excavation of Ban Non Wat: Introduction, Bangkok, The Thai Fine Arts Department.

Kanthilatha, N., Boyd, W. \& Chang, N. 2014a. Multi-Element Characterisation of Archaeological Floors at the Prehistoric Archaeological Site Ban Non Wat and Nong Hua Raet in Northeast Thailand. Quaternary International, In Press: $1-13$

Kanthilatha, N., Boyd, W., Dowell, A., Mann, A., Chang, N., Wohlmuth, H. \& Parr, J. 2014b. Indentification of Preserved Faty Acids in Archaeological Floor Sediments from Prehistoric Site Ban Non Wat and Nong Hua Raet in Northeast Thailand Using Gas Chromatography. Journal of Archaeological Science, 46: 343-362.

McGrath, R. J. 2001. Geoarchaeology of the Iron Age Flooplain Moats of Northeast Thailand. PhD, Southern Cross University, Lismore.

McGrath, R. J. \& Boyd, W. E. 2001. The Chronology of the Iron Age 'Moats' of Northeast Thailand. Antiquity, 75(288): 349-360

McGrath, R. J., Boyd, W. E. \& Bush, R. T. 2008. The Paleohydrological Context of the Iron Age Floodplain Sites of the Mun River Valley, Northeast Thailand Geoarchaeology: An International Journal, 23(1): 151-172.

McNeill, J. R. \& Welch, D. J. 1991. Regional and Interregional Interaction on the Khorat Plateau. Indo-Pacific Prehistory Association Bulletin, 10: 327-340.

Moore, E. 1989. Water Management in Early Cambodia. The Geographical Journal. 155(2): 204-213.
Moore, E. 1988. Notes on two Types of Moated Settlement in Northeast Thailand. Journal of the Siam Society. 76: 275287.

Murphy, S. 2013. The Distribution of Sema Stones throughout the Khorat Plateau during the Dvaravati Period. In Klokke, M. J. and Degroot, V. (eds) Selected Papers from the $12^{\text {th }}$ International Conference of the European Association $f$ Southeast Asian Archaeologist, Volume 1. Singapore: NUS Press: 215-233.

O'Reilly, D. J. W. 2014. Increasing Complexity and Political Economy Model; a Consideration of Iron Age Moated Sites in Thailand. Journal of Anthropolgical Archaeology, 35: 297-309.

Persson, K. \& Olofsson, B. 2004. Inside a Mound: Applied Geophysisc in Archaeological Prospecting at the Kings' Mounds, Gamla Uppsala, Sweden. Journal of Archaeological Science, 31(5): 551-562.

Sarris, A., Papadopoulos, N., Agapiou, A., Salvi, M. C., Hadjimitsis, D. G., Parkinson, W. A., Yerkes, R. W., Gyucha, A. \& Duffy, P. R. 2013. Integration of Geophysical Surveys, Ground Hyperspectral Measurements, Aerial and Satellite Imagery for Archaeological Prospection of Prehistoric Sites: The Case Study of Veszto-Magor Tell, Hungary. Journal of Archaeological Science, 40: 14541470 .

Sonnemann, T. 2015a. Spatial Configurations of Water Management at an early Angkorian capital - Combining GPR and TerraSAR-X data to complement an archaeological map. Archaeological Prospection. DOI: 10.1002/arp.1502

Sonnemann, T. 2015b. Classification of Geophysical data of Angkor, Cambodia, and its potential as an online source. In Traviglia, A. (ed) Across Space and Time - Papers from the $41^{\text {st }} C A A$, Perth 25-28 March 2013. Amsterdam University Press: 64-69.

Sonnemann, T. F. 2011. Angkor Underground-Appling GPR to Analyse the Diachronic Structure of a Great Urban Complex. Unpublished PhD, University of Sydney, Sydney.

Sonnemann, T. F. \& Chhay, R. 2014. Non-Destructive GPR Analysis of Threatened Angkorian Ceramic Kilns at Bangkong, Siem Reap, Cambodia. Journal of IndoPacific Archaeology, 34: 42-50.

Urban, T. M., Vella, C., Bocancea, E. \& Tuttle, C. A. 2014. A Geophysical Investigation of a Newly Discovered Early Bronze Age Site near Petra, Jordan. Journal of Archaeological Science, 42: 260-272.

Welch, D. J. 1989. Late Prehistoric and Early Historic Exchange Patterns in the Phimai Region, Thailand. Journal of Southeast Asian Studies, 20: 11-26.

Welch, D. J. 1998. Archaeology of Northeast Thailand in Relation to the Pre-Khmer and Khmer Historical Records. International Journal of Historical Archaeology, 2(3): 205233.

Welch, D. J. \& McNeill, J. R. 1991. Settlement, Agriculture and Population Changes in the Phimai Region, Thailand. Indo-Pacific Prehistory Association Bulletin, 10: 210-228.

Whittaker, W. E. \& Storey, G. R. 2008. Ground-Penetrating Radar Survey of the Sny Magil Mound Group, Effigy Munds National Monument, Iowa. Geoarchaeology: An International Journal, 23(4): 474-499.

Williams-Hunt, P. D. R. 1950. Irregular Eathworks in Eastern Siam: An Air Survey. Antiquity, 24: 30-36. 
Yankowski, A., Kerdsap, P. \& Chang, N. 2015. "Please Pass the Salt"- an Ethnoarchaeological Study of Salt and Salt Fermented Fish Producion, Use and Trade in Northeast Thailand. Journal of Indo-Pacific Archaeology, 37: 4-13.

Yong, Y., Dakui, Z., Wenwu, T. \& Peter, M. I. 2001. The Application of GPR to barrier-lagoon sedimentation study in Boao of Hainan Island, 12(3): 313-320. 